\title{
РЕФОРМУВАННЯ МЕДИЧНОЇ ОСВІТИ В АВСТРІЇ: ЗРАЗОК УСПШШНОГО ПРОВЕДЕННЯ І ПРИКЛАД ДЛЯ НАСЛІДУВАННЯ
}

Тернопільський державний медичний університет імені І. Я. Горбачевського

\section{REFORMATION OF MEDICAL EDUCATION IN AUSTRIA: A MODEL OF SUCCESSFUL IMPLEMENTATION AND EXAMPLE FOR IMITATION}

H. I. Klishch

\author{
Ternopil State Medical University by I. Ya. Horbachevsky
}

\begin{abstract}
У статті узагальнено австрійський досвід реформування медичної освіти. Розглянуто головні фундаментальні зміни у нових навчальних планах медичних університетів Австрії, їх переваги та наслідки.
\end{abstract}

In this article the Austrian experience in reformation of medical education is summarized. The main fundamental changes in new curriculum of medical universities of Austria, their advantages and consequences are examined.

Вступ. 3 огляду на підписання Болонської декларації, сучасна українська медична освіта зараз перебуває у стані перебудови. Основні ії проблеми - це невідповідність стандартам СС, Всесвітньої федерації медичної освіти (ВФМО) і вимогам часу; зниження якості підготовки медичних кадрів внаслідок низької мотивації студентів і викладачів до самовдосконалення; відсугність університетських клінік; застосування застарілих педагогічних технологій, низький рівень соціального захисту викладачів, інформатизації навчального процесу і самостійної роботи студентів [1].

Будь-яке реформування - складний і болісний процес. Впровадженню змін перешкоджають нерозуміння викладачами та громадськістю завдань і мети реформ, недосконалість законодавства, недостатність фінансування вищої школи, надмірне академічне навантаження викладачів тощо. Однак реформування медичної освіти - єдиний шлях нашої держави, надання кожному громадянину сучасної медичної допомоги, а студентам - можливості здобути освіту світового рівня, стати високопрофесійним і конкурентоспроможним фахівцем [2].

Протягом останнього часу відбулися зміни у нормативній базі вищої медичної школи (перехід на нові навчальні плани, упровадження програм кредитномодульної системи організації навчального процесу, введення державної атестації згідно з вимогами якості освіти тощо). Успішно здійснюється процес оновлення матеріально-технічної бази навчальних закладів, упровадження нових технологій організації навчально(с) Г. І. Кліщ го процесу, розроблено проект Концепції реформування післядипломної освіти [2].

У процесі проведення реформ важливим є досвід інших країн, особливо тих, де ці реформи вже приносять певні плоди. Зважаючи на це, метою статті $є$ узагальнення результатів реформування медичної освіти в Австрії, яка розпочала цей процес у 2002 році і має значні напрацювання та позитивні результати, які можуть бути використані в Україні.

Основна частина. Протягом останнього десятиліття Австрія пережила фундаментальні зміни у медичній освіті, наслідки яких торкнулися всього освітнього процесу - від процедури зарахування на навчання до післядипломної підготовки [6].

До запровадження нових правил старі структури, починаючи з часів монархії, були такими ж, як і тоді, коли вони були описані Теодором Більротом в йогопраці “Про викладання та вивчення медичної науки в університетах німецької нації, разом із зауваженнями загального характеру про університети, культурно-історичні дослідження" у 1876 році [4]. Останнім нормативним актом перед проведенням реформи, який регламентував університетську освіту, був Закон про університетське навчання 1997 року (Universitatsstudiengesetz 1997), згідно 3 яким у медичній освіті австрійських університетів залишалась традиційна уніфікована програма (табл. 1). Упроваджена відповідно із законом уніфікація навчальних планів у медичних університетах Відня, Інсбрука та Граца полегшувала внутрішньоавстрійську мобільність студентів. Проте це не використовувалось 
Tаблиця 1. Структура уніфікованого навчального плану медичних факультетів Австрії відповідно до Закону про університетську освіту 1997 року

\begin{tabular}{|c|c|c|c|c|c|}
\hline \multirow{2}{*}{ Предмет } & \multirow{2}{*}{ Код / семестри } & \multicolumn{3}{|c|}{ Годин } & \multirow{2}{*}{ Кредитів } \\
\hline & & лекцій & практичних & разом & \\
\hline \multicolumn{6}{|c|}{ Доклінічні дисципліни (4 семестри) } \\
\hline Медична фізика & 1MED Mphy/1 & 90 & 15 & 105 & 11 \\
\hline Медична хімія & 1MED Mche/1 & 120 & 60 & 180 & 16 \\
\hline Медична біологія & 1MED Mbio/1,2 & 75 & 15 & 90 & 9 \\
\hline Анатомія & 1-2MED Anat $/ 2,3$ & 180 & 125 & 305 & 28 \\
\hline Гістологія та ембріологія & 1-2MED His/2,3 & 90 & 195 & 285 & 15 \\
\hline Медична біохімія & $2 \mathrm{MED}$ Bioc/4 & 105 & 60 & 165 & 14 \\
\hline Медична фізіологія & 2 MED Phys/4 & 120 & 90 & 210 & 27 \\
\hline \multicolumn{5}{|l|}{ Всього } & 120 \\
\hline \multicolumn{6}{|c|}{ Теоретично-клінічні дисципліни (3 семестри) } \\
\hline Медична психологія & 3-4 MED Mpsy/5-7 & 45 & 15 & 60 & 3 \\
\hline Загальна патологія & 3-4 MED GePa/5-7 & 135 & 120 & 28 & 28 \\
\hline Функціональна патологія & 3-4 MED FuPa/5-7 & 120 & 30 & 150 & 22 \\
\hline Радіологія & 3-4 MED Rad/5-7 & 45 & 15 & 60 & 7 \\
\hline Гігієна і мікробіологія & 3-4 MED Hyg/5-7 & 120 & 30 & 150 & 9 \\
\hline Фармакологія і токсикологія & 3-4 MED Phar/5-7 & 120 & 45 & 165 & 21 \\
\hline \multicolumn{4}{|l|}{ Всього } & & 90 \\
\hline \multicolumn{6}{|c|}{ Клінічні дисципліни (5 семестрів) } \\
\hline Внутрішні хвороби & 4-6 MED IntMed/8-12 & 345 & 120 & 465 & 31 \\
\hline Хірургія & 4-6 MED Surg/8-12 & 345 & 120 & 465 & 24 \\
\hline Педіатрія & 4-6 MED Ped/8-12 & 150 & 60 & 210 & 17 \\
\hline Гінекологія та акушерство & 4-6 MED Gyn/8-12 & 180 & 75 & 255 & 17 \\
\hline Психіатрія & 4-6 MED Psyc/8-12 & 90 & 30 & 120 & 10 \\
\hline Неврологія & 4-6 MED Neur/8-12 & 90 & 30 & 120 & 10 \\
\hline Офтальмологія & 4-6 MED Opht/8-12 & 75 & 30 & 105 & 6 \\
\hline Дерматологія і венерологія & 4-6 MED Derm/8-12 & 90 & 30 & 120 & 16 \\
\hline Оториноларингологія & 4-6 MED Otol/8-12 & 60 & 15 & 75 & 7 \\
\hline Соціальна медицина & 4-6 MED SocM/8-12 & 45 & 15 & 60 & 3 \\
\hline Судова медицина & 4-6 MED ForM/8-12 & 75 & 15 & 90 & 6 \\
\hline Стоматологія & 4-6 MED Dent/8-12 & 30 & 15 & 45 & 3 \\
\hline \multicolumn{4}{|l|}{ Всього } & & 150 \\
\hline
\end{tabular}

у прямому розумінні слова, а ставало причиною для такого собі екзаменаційного туризму студентів. Іноді сотні студентів уникали “важких" екзаменів в одному університеті, змінивши на семестрових канікулах місце навчання на інший, з явно “легшими” екзаменами. Успішно склавши їх там, вони повертались, по можливості, під час семестрових канікул на початкове місценавчання [7].

З 1999 року три медичних факультети австрійських університетів були залучені до розробки абсолютно нової програми підготовки лікарів. Імплементація цієї реформи розпочалась у 2002 році із прийняттям Федеральним парламентом Австрії “Закону про університети 2002 року” (Universitatsgesetz 2002). Цей процес різко прискорився із зміною організаційної структури університетів: у 2004 році від трьох класичних університетів - Відня, Інсбрука і Граца від'єдналися медичні факультети, в результаті чого було створено три незалежних медичних університети, які набули статусу повної автономії [10].

До 2004 року логіка і структура професійної підготовки майбутніх медиків була традиційною. Значна кількість прогресивних викладачів, а особливо навчальні комісії, були незадоволені процесом організації навчання за уніфікованою програмою, вказуючи на такі основні недоліки:

- основна структура навчальної програми з медицини була застарілою;

- навчання здійснювалось без чіткого узгодження дисциплін між собою. Міжпредметний дидактичний підхід існував лише в обрисах. До дискусій про зміст предметів доходило хіба що через скарги студентів про надмірну кількість матеріалу на екзаменах;

- через ізольовану автономію предметів і відокремленість наукових структурних одиниць (інститути і клініки) при відсутньому центральному управлінні 
навчання було для студентів свого роду бігом 3 перешкодами від установи до установи, у процесі якого поставало питання швидшого пристосування до відповідних місцевих правил;

- навчальний план передбачав для першого (“"передклінічного") періоду навчання чотири семестри, для другого (“міжклінічного”) періоду - три, а для третього (“клінічного") навчального періоду - п'ять семестрів. Реальність свідчила про те, що перші навчальні періоди для багатьох студентів тривали до семи або восьми років; а клінічний період, навпаки, часто “закінчували” протягом двох або максимум трьох семестрів у формі “заочного навчання”;

- перші два навчальні періоди, які у такий спосіб домінували у часовому відношенні у навчанні, мали майже повністю теоретичний характер. Такого важливого для подальшої професії контакту з пацієнтами майже не було, у дійсності він зводився до надто короткого клінічного навчального періоду.

Результатом такого навчання була непридатність випускників для практики [9].

Прийом на медичні факультети був повністю безкоштовним. Будь-який випускник, що отримав середню освіту, мав право зареєструватися на навчання. Цей підхід привів до величезного напливу студентів (до 1800 студентів-першокурсників у Віденському медичному університеті у 80-х роках XX століття) та не дозволяв проводити ретельнепланування курсу. Відсоток відсіву був дуже високим: близько 50 \% студентів; причому приблизно дві третини студентів були відраховані протягом “доклінічного періоду”, тобто ще до приходу їх у клініку. Хоча навчальний план був розрахований на шестирічний термін, середній час завершення навчання становив білыше восьми років [6].

Медичний факультет у Іраці отримав фінансування у фонді Австрійського національного банку на дослідницький проект, проведений позаштатними науковцями, темою якого стало оцінювання традиційного навчання медицини за уніфікованою програмою. Це єдине у своєму роді австрійське дослідження (SCHOBER, Spiel \& REIMANN, 2004) охопило опитуванням всіх суб' єктів навчального процесу (студентів, викладачів, випускників, лікарів практичної ланки, а також головних лікарів як “замовників” студентів-випускників).

Дослідження в основному підтвердило наведені вище недоліки, а пов' язані з цим наслідки вказували на таке:

- навчання студентів мало переважно теоретичне спрямування. Практичному досвіду не надавали належної уваги, лікарським навичкам і такому важливому аспекту роботи лікаря, як здатності до комуні- кації з іншими людьми, здатності до критичного спостереження і психосоціальній компетенції взагалі не навчали і не тренували, або якщо це і робили, то у недостатньому об' ємі.

- відповідно, професійна підготовка лікаря, що здійснювалася після навчання, була для випускників і випускниць у справжньому розумінні “стрибком у крижану воду” разом з високою мірою невпевненості та фрустрації [12].

Зважаючи на це, а також на відповідні настрої у суспільстві, де побутувало незадоволення рівнем підготовки лікарів, було вирішено провести масштабне реформування медичної освіти.

Визначальними для дискусій про розробку змісту навчальноїпрограмисталивідомі європейськіосновоположні документи (GENERALMEDICALCOUNCILUK, 1993, 2003; ASSOCIATION OF UNIVERSITIES IN THE NETHERLANDS, 1994, 2001; JOINT COMMISSIONOF THE SWISS MEDICAL SCHOOLS, 2001).

У процесі розробки кваліфікаційного профілю для випускників за новою навчальною програмою значна увага була приділена ліквідації дисбалансу між теоретичним навчанням та обмеженою підготовкою до практичної лікарської діяльності. На відносно ранніх стадіях дискусії про реформи, завдяки внеску зовнішніх експертів, була майже повна одностайність стосовно того, що традиційну послідовність спеціальних дисциплін (доклінічні, теоретично-клінічні та клінічні) потрібно замінити на сучасну тематично спрямовану навчальну програму, побудовану на модульній основі, де окремі предмети мають взаємодіяти в інтегрованому контексті [3]. Вирішальним було питання про те, як зреалізувати такого роду новий фундаментальний план реорганізації медичної освіти. Проглядався великий потенціал конфліктів, оскільки традиційні предмети втратили приблизно 40 $\%$ часового ресурсу, який був необхідним для запровадження нового змісту навчання [5].

План реорганізації передбачав повну “ліквідацію” предметів, представлених, зазвичай, науковими структурними підрозділами, оскільки група реформаторів побоювалась, що представники цих предметів будуть вести “боротьбу за виживання", яка унеможливить справжню реформу. Тому було вирішено зробити наступним чином. У той час як при найменуванні нових модулів надавали значення тому, щоб не допускати ніякого наслідування назв існуючих спеціальних дисциплін, було вирішено, що кожному структурному підрозділу, який ототожнювався з традиційним предметом, мала дістатись “роль приймаючого господаря” для певного модуля навчальної програми. Цей план 
мав цілий ряд позитивних наслідків. "Роль приймаючого господаря" вирішальним чином допомогла існуючим структурним підрозділам ідентифікувати себе 3 новою моделлю організації і краще перенести втрату “верховенства" над названим предметом. Через ідентифікацію з відповідним модулем, заради якого виконувалась функція “"приймаючого господаря”, виникало відчуття відповідальності за цей модуль, а разом 3 цим і за змістову та організаційну координацію задіяних структурних підрозділів та викладачів [8]. Це було важливо як для змістової концепції, так і для конкретного здійснення навчального та екзаменаційного процесу. У такий спосіб стало можливим також успішнодати необхідне визначення основній організаційній структурі нової навчальної програми. Було досягнуго одностайності у тому, що визначальною парадигмою нової дипломної освіти є “біологічно-психосоціальна модель”. Навчальний процес організовувався таким чином, щоб студенти навчалися і сприймали пацієнтів як цілісних особистостей у їх фізичному та духовному вимірах, з їх статусом у відповідних соціальних структурах і системах [14].

Медичні університети в Австрії цілком вільні у побудові і структурі своїх навчальних програм. Тим не менше, нові навчальні програми, які були розроблені ними незалежно один від одного, мають значну подібність [13]. Важливими наріжними каменями для їх розробки стали:

- ранній контакт з найрізноманітнішими аспектами охорони здоров'я;
- поєднання глибокого науково-теоретичного навчання з інтенсивною практичною лікарською підготовкою;

- інтенсивне навчання комунікації, самоаналізу та догляду за пацієнтами;

- інтегративний підхід до перебудови змісту медичної освіти;

- залучення студентів до наукових досліджень [10].

Процес професійної підготовки майбутніх медиків був повністю реорганізований на основі компетентнісного підходу. Навчальні плани, які до цього мали вигляд дворівневої моделі (доклінічна/клінічна фази), були реструктуровані в інтегровані модулі з одним циклом. Модулі та додаткові курси, такі, як відпрацювання практичних вмінь і навичок, інтегрувалися як по горизонталі, так $\mathrm{i}$ по вертикалі. Кількість іспитів значно зменшилась, хоча із місцевими відмінностями - в університетах Відня та Інсбрука студенти складають комплексний тестовий іспит з усіх модулів, які вони проходили за рік, а у Граці завершення кожного модуля супроводжується складанням іспиту [12]. У більшості випадків оцінювання знань студентів здійснюється шляхом проведення письмових тестових іспитів, хоча практичні навички іноді оцінюються за участю викладача. 3 метою розвитку наукового мислення і сприяння залученню до наукових досліджень усі студенти зобов'язані написати дипломну роботу, яка планується, виконується і захищається під час останнього року навчання [11]. Структура навчального плану Віденського медичного університету відображена у таблиці 2.

Таблиця 2. Структура навчального плану Віденського медичного університету після проведення реформи

\begin{tabular}{|c|c|c|c|c|}
\hline \multirow{2}{*}{ Назва модуля (лінії) } & \multirow{2}{*}{ Код / модуль (лінія) } & \multicolumn{3}{|c|}{ Кредитів ECTS } \\
\hline & & лекцій & практичних & разом \\
\hline \multicolumn{5}{|c|}{ Перший рівень навчання (2 семестри) } \\
\hline \multicolumn{5}{|c|}{ Семестр 1} \\
\hline Здорова і хвора людина & 1DIPLM/M1 & 4,9 & 1,7 & 6,6 \\
\hline Людське тіло & 1DIPLM/M2 & 10,7 & 1,2 & 11,9 \\
\hline Від молекули до клітини & 1DIPLM/M3 & 9,3 & 2,6 & 11,9 \\
\hline Соціальна компетенція & 1DIPLM/L1 & 0,2 & 2,8 & 3,0 \\
\hline Перша допомога I & 1DIPLM/ L2A & 0,6 & & 0,6 \\
\hline Факультативні предмети & 1DIPLM/ OPT1 & & & 0,7 \\
\hline \multicolumn{4}{|l|}{ Разом за семестр } & 34,7 \\
\hline \multicolumn{5}{|c|}{ Семестр 2} \\
\hline $\begin{array}{l}\text { Функціональні системи та біологічна } \\
\text { регуляція }\end{array}$ & 1DIPLM/M4 & 8,9 & 1,5 & 10,4 \\
\hline $\begin{array}{l}\text { Генетика, молекулярні та клітинні } \\
\text { зв’язки }\end{array}$ & 1DIPLM/M5 & 4,2 & 1,8 & 6,0 \\
\hline $\begin{array}{l}\text { Людина в навколишньому } \\
\text { середовищі, сім’ї і суспільстві }\end{array}$ & 1DIPLM/M6 & 4,9 & 1,1 & 6,0 \\
\hline
\end{tabular}


Продовження табл. 2

\begin{tabular}{|c|c|c|c|c|}
\hline \multirow{2}{*}{ Назва модуля (лінії) } & \multirow{2}{*}{ Код / модуль (лінія) } & \multicolumn{3}{|c|}{ Кредитів ECTS } \\
\hline & & лекцій & практичних & разом \\
\hline \multicolumn{5}{|c|}{ Семестр 2} \\
\hline Перша допомога II & 1DIPLM/L2B & & 1,1 & 1,1 \\
\hline $\begin{array}{l}\text { Фізикальні методи обстеження здорової } \\
\text { людини }\end{array}$ & 1DIPLM/L3A & & 1,1 & 1,1 \\
\hline Факультативні предмети & 1DIPLM/ OPT2 & & & 0,7 \\
\hline \multicolumn{4}{|l|}{ Разом за семестр } & 25,3 \\
\hline \multicolumn{4}{|l|}{ Всього за рік } & 60 \\
\hline \multicolumn{5}{|c|}{ Другий рівень навчання (4 семестри) } \\
\hline \multicolumn{5}{|c|}{ Семестр 3} \\
\hline Наука і медицина & 2DIPLM/M7 & 1,4 & 4,3 & 5,7 \\
\hline Хвороби, їх походження та симптоматика & 2DIPLM/M8 & 8,2 & 3,1 & 11,3 \\
\hline $\begin{array}{l}\text { Хвороби, їх прояви, клініка, загальна } \\
\text { фармакотерапія }\end{array}$ & 2DIPLM/M9 & 6,3 & 5,0 & 11,3 \\
\hline Збирання лікарського анамнезу А & 2DIPLM/ L4A & & 1,1 & 1,1 \\
\hline Основні медичні навички & 2DIPLM/ L5 & & 1,1 & 1,1 \\
\hline Проблемно-орієнтоване навчання & 2DIPLM/ L6 & & 2,1 & 2,1 \\
\hline Факультативні предмети & 2DIPLM /OPT3 & & 0,7 & 0,7 \\
\hline \multicolumn{4}{|l|}{ Разом за семестр } & 33,2 \\
\hline \multicolumn{5}{|c|}{ Семестр 4} \\
\hline Ендокринологія і обмін речовин & 2DIPLM/M10 & 4,2 & 1,6 & 5,8 \\
\hline Серцево-судинна система і кров & 2DIPLM/M11 & 6,2 & 4,2 & 10,4 \\
\hline Дихальна система & 2DIPLM/M12 & 3,7 & 2,0 & 5,7 \\
\hline Збирання лікарського анамнезу В & 2DIPLM/L2B & & 0,5 & 0,5 \\
\hline $\begin{array}{l}\text { Фізикальні методи обстеження здорової } \\
\text { людини }\end{array}$ & 2DIPLM/L3B & & 1,1 & 1,1 \\
\hline Проблемно-орієнтоване навчання & 2DIPLM /L7 & & 2,1 & 2,1 \\
\hline Пропедевтика в протоколах & 2DIPLM /L8 & & 0,5 & 0,5 \\
\hline Факультативні предмети & 2DIPLM /OPT4 & & & 0,7 \\
\hline \multicolumn{4}{|l|}{ Разом за семестр } & 26,8 \\
\hline \multicolumn{4}{|l|}{ Всього за рік } & 60 \\
\hline \multicolumn{5}{|c|}{ Семестр 5} \\
\hline Харчування і травлення & 3DIPLM/M13 & 4,1 & 2,6 & 6,7 \\
\hline Нирки і гомеостаз & 3DIPLM/M14 & 3,4 & 1,7 & 5,1 \\
\hline $\begin{array}{l}\text { Сексологія, репродукція, вагітність і } \\
\text { пологи }\end{array}$ & 3DIPLM/M15 & 5,0 & 1,7 & 6,7 \\
\hline Новонароджені, дитячий та підлітковий вік & 3DIPLM/ L4A & 5,5 & 1,3 & 6,8 \\
\hline Проблемно-орієнтоване навчання & 3DIPLM/ L9 & & 1,9 & 1,9 \\
\hline Реанімаційні заходи I & 3DIPLM/ L10A & & 0,9 & 0,9 \\
\hline Спеціальні методи дослідження I & 3DIPLM/ L11A & & 0,9 & 0,9 \\
\hline Клінічні протоколи & 3DIPLM/ CLS1 & & & 2,0 \\
\hline Факультативні предмети & 3DIPLM /OPT5 & & & 0,7 \\
\hline \multicolumn{4}{|l|}{ Разом за семестр } & 31,7 \\
\hline \multicolumn{5}{|c|}{ Семестр 6} \\
\hline Методологія медичної науки SSM2 & 3DIPLM/M17 & 1,0 & 4,0 & 5,0 \\
\hline Шкіра та органи чуття & 3DIPLM/M18 & 5,0 & 1,7 & 6,7 \\
\hline Мозок, нервова система і біль & 3DIPLM/M19 & 8,1 & 1,9 & 10,0 \\
\hline Неврологічний статус & 3DIPLM /L12 & & 0,9 & 0,9 \\
\hline Проблемно-орієнтоване навчання & 3DIPLM /L13 & & 1,9 & 1,9 \\
\hline Протоколи & 3DIPLM/ CLS2 & & & 2,0 \\
\hline Факультативні предмети & 3DIPLM /OPT6 & & & 0,7 \\
\hline Збирання лікарського анамнезу В & 3DIPLM/ L4C & & 0,9 & 0,9 \\
\hline \multicolumn{4}{|l|}{ Разом за семестр } & 28,3 \\
\hline \multicolumn{4}{|l|}{ Всього за рік } & 60 \\
\hline
\end{tabular}




\begin{tabular}{|c|c|c|c|c|c|c|}
\hline & & & & & Іродовженн & табл \\
\hline \multirow{2}{*}{\multicolumn{2}{|c|}{ Назва модуля (лінії) }} & \multirow{2}{*}{\multicolumn{2}{|c|}{$\begin{array}{c}\text { Код / модуль } \\
\text { (лінія) }\end{array}$}} & \multicolumn{3}{|c|}{ Кредитів ЕCTS } \\
\hline & & & & лекцій & практичних & разом \\
\hline \multicolumn{7}{|c|}{ Третій рівень навчання (6 семестрів) } \\
\hline \multicolumn{7}{|c|}{ Семестр 7} \\
\hline \multicolumn{2}{|c|}{ Психічні функції у здорової та хворої людини } & \multicolumn{2}{|c|}{ 4DIPLM/M20 } & 6,8 & 4,1 & 10,9 \\
\hline \multicolumn{2}{|l|}{ Опорно-руховий апарат } & \multicolumn{2}{|c|}{ 4DIPLM/M21 } & 7,0 & 1,7 & 8,7 \\
\hline \multicolumn{2}{|c|}{ Здоров'я, навколишнє середовище, професійні хвороби } & \multicolumn{2}{|c|}{ 4DIPLM/M22 } & 6,8 & 2,0 & 8,8 \\
\hline \multicolumn{2}{|l|}{ Проблемно-орієнтоване навчання } & \multicolumn{2}{|c|}{ 4DIPLM/ L16 } & & 2,5 & 2,5 \\
\hline \multicolumn{2}{|l|}{ Спеціальні методи обстеження } & \multicolumn{2}{|c|}{ 4DIPLM/ L11B } & & 0,6 & 0,6 \\
\hline \multicolumn{2}{|l|}{ Основи ультрасонографії } & \multicolumn{2}{|c|}{ 4DIPLM/ L15 } & & 0,6 & 0,6 \\
\hline Спеціальні діагностичні практичні & вички & 4DI & M/ L14 & & 1,2 & 1,2 \\
\hline Факультативні предмети & & $4 \mathrm{DIP}$ & M /OPT7 & & & 0,7 \\
\hline Клінічні протоколи & & $4 \mathrm{DIF}$ & M/ CLS3 & & & 2,0 \\
\hline Разом за семестр & & & & & & 35,8 \\
\hline & $\mathrm{CeM}$ & естр 8 & & & & \\
\hline Лікар і етика & & 4DI & M/M23 & 5,4 & 3,3 & 8,7 \\
\hline Проектове навчання SSM3 & & 4DI & M/M24 & 1,3 & 7,2 & 8,5 \\
\hline Реанімаційні заходи та невідкладна & опомога II & 4DIF & $\mathrm{M} / \mathrm{L} 10 \mathrm{~B}$ & & 0,6 & 0,6 \\
\hline Факультативні предмети & & 4DIP & M/ OPT8 & & & 0,7 \\
\hline Проблемно-орієнтоване навчання & & $4 \mathrm{DI}$ & M/L17 & & 2,5 & 2,5 \\
\hline Спеціальні методи обстеження II & & $4 \mathrm{DIF}$ & $\mathrm{M} / \mathrm{L} 11 \mathrm{C}$ & & 1,2 & 1,2 \\
\hline Клінічні протоколи & & 4DIP & A / CLS4 & & & 2,0 \\
\hline Разом за семестр & & & & & & 24,2 \\
\hline Всього за рік & & & & & & 60 \\
\hline & & & & Кредит & ECTS & \\
\hline Предмет & Код / модуль ( & інія) & лекції & $\begin{array}{c}\text { практичні, } \\
\text { семінари }\end{array}$ & $\begin{array}{c}\text { клінічна } \\
\text { практика }\end{array}$ & разом \\
\hline & $\mathrm{CeM}$ & естр 9 & & & & \\
\hline Внутрішня медицина I & 5DIPLM/ INTM & & & 3,3 & 3,3 & 6,6 \\
\hline Внутрішня медицина II & 5DIPLM/ INTM & & & 2,5 & 3,3 & 5,8 \\
\hline Невідкладна допомога & 5DIPLM/EMM & & 1,1 & 1,4 & 3,3 & 5,8 \\
\hline Клінічна діагностика & 5DIPLM/ L18 & & & 3,3 & & 3,3 \\
\hline Загальна медична практика & 5DIPLM/ L19A & & & 1,2 & & 1,2 \\
\hline & Сем & стр 10 & & & & \\
\hline Хірургія I & 5DIPLM/ SURC & & & 3,3 & 3,3 & 6,6 \\
\hline Хірургія II & 5DIPLM/ SURC & & & 2,5 & 3,3 & 5,8 \\
\hline Прикладні медичні науки & 5DIPLM/ AMSC & & 1,1 & 3,9 & & 5,0 \\
\hline Факультативні предмети & 5DIPLM / OPT & & & & & 1,5 \\
\hline Клінічні протоколи & 5DIPLM/ CLS5 & & & & & 8,0 \\
\hline Дипломна робота A & 5DIPLM / THE & & & & & 10,0 \\
\hline Всього за рік & & & & & & 60 \\
\hline & Сем & стр 11 & & & & \\
\hline Неврологія & 6DIPLM/NEUR & & 1,1 & 1,9 & 2,8 & 5,8 \\
\hline Психіатрія & 6DIPLM/PSYC & & 1,1 & 2,2 & 2,5 & 5,8 \\
\hline Педіатрія & 6DIPLM/PED & & 1,1 & 1,4 & 3,3 & 5,8 \\
\hline Загальний догляд за пацієнтами & 6DIPLM /L20 & & & 3,3 & & 3,3 \\
\hline Загальна практика & 6DIPLM /L19B & & & & 1,3 & 1,3 \\
\hline & Сем & стр 12 & & & & \\
\hline Акушерство та гінекологія & 6DIPLM/ GYN & & & 2,5 & 3,3 & 5,8 \\
\hline Офтальмологія & 6DIPLM/ OPHT & & 0,8 & 0,8 & 1,3 & 3,9 \\
\hline Оториноларингологія & 6DIPLM/ ORL & & 1,1 & 0,8 & 1,4 & 3,3 \\
\hline Дерматологія & 6DIPLM / DER & & 0,8 & 1,9 & 1,4 & 4,2 \\
\hline Прикладні медичні науки II & 6DIPLM / AMS & & 0,3 & 1,4 & & 1,7 \\
\hline Факультативні предмети & 6DIPLM/ OPHT & & & & & 1,5 \\
\hline Дипломна робота В & 6DIPLM / THE & & & & & 10,0 \\
\hline Клінічні протоколи & 6DIPLM/ CLS6 & & & & & 8,0 \\
\hline $\mathrm{Bc}$ & & & & & & 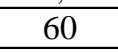 \\
\hline
\end{tabular}


Однією з найбільших проблем, що тривалий час не вирішувалася і гальмувала реформування медичної освіти, був безкоштовний вступ до вищих навчальних закладів Австріі. До рішення суду СС у 2005 році в країні був політичний консенсус стосовно того, що в країні має бути дозволений необмежений допуск до вступу в університети. Однак це входило в протиріччя 3 можливостями медичних факультетів. Вибір був в основному самовибором [10]. Упровадження процедури попереднього відбору докорінно змінило стан справ. У сучасних умовах співвідношення заяв на вступ становить приблизно п'ять до одного. Абсолютно нові і незнайомі процедури прийому були предметом палких суперечок на території всієї країни. У ході обговорення панувала помилкова думка, що вступні випробування повинні мати прогностичне значення, гарантуючи, що випускники будуть “хорошими" лікарями, у той час як процедура була задумана як спосіб справедливого відбору, що базується на академічній успішності вступника. Однак у процесі проведення вступних випробувань і Свропейська система здатності до опанування медицини (EMS), яку використовують Віденський та Інсбрукський медичні університети, і місцева система вступних випробувань застосовується медичним університетом Граца) добре себе зарекомендували [14].

Зважаючи на автономію австрійських університетів, кожен з них використовує різні процедури прийому. Медичніуніверситети Відня та Інсбрука вирішили співпрацювати в цьому плані і застосовують відомий інструмент для перевірки академічних здібностей абітурієнтів, так званий "Eignungstest fur das Medizinstudium in Osterreich" (EMS, тест на придатність до вивчення медицини в Австріi), а в Граці використовують самостійно розроблені викладачами університету тести для перевірки знань $з$ профільних предметів (біології, хіміі, математики, фізики) [13].

В Австрії досвід впровадження тестових вступних випробувань виявив разючий контраст $з$ попереднім досвідом у Німеччині та Швейцарії - результати тестування у жінок були значно гіршими, ніж у чоловіків в усіх трьох університетах. Тому виникли дебати щодо подолання цього гендерного розриву. Було поглиблено проаналізовано процедуру допуску до вступних випробувань та можливі основні причини гендерних відмінностей, які були зумовлені відмінностями у процесі їх соціалізації в системі середньої освіти [3].

У 2002 році в австрійське законодавство було впроваджено елементи Болонського процесу, що стосуються медичної освіти (наприклад, забезпечення контролю якості освіти, впровадження кредитів ECTS, європейського додатка до диплома). 3 метою ліквідації основного джерела опору змінам медична освіта була побудована як одноетапний шестирічний дипломний курс. Поправки до закону 2009 року, які вступлять в силу у 2012 році, змінять одноетапну модель навчального плану на двоетапну, в якій будуть реалізовані нові навчальні програми медичної освіти. Існуючі навчальні програми можуть залишатися незмінними, але медичні університети в змозі будуть вільно обирати навчання в системі бакалаврмагістр, якщо вони захочуть це зробити [3].

Наслідки змін протягом останнього десятиліття можуть бути визначені на різних рівнях системи освіти університетському, національному і міжнародному.

Нові навчальні структури потребували інших методів управління та керівництва. Перехід від навчальної організації з чіткою послідовністю дисциплінарних ліній до комплексних інтегрованих програм з тематичною модульною організацією допомогло перемістити децентралізовані ресурси на новий, більш високий рівень організаційної структури в межах університету (хоча деталі відрізняються у різних університетах). Зміст та контроль знань плануються координаторами, які відповідають за модулі чи різні фази навчальної програми. Як результат формується основна структура міждисциплінарних зв' язків, яка повністю відрізняється від попередньої структури, заснованої на дискретних предметах [5].

Важливими стали зміни до нових методів оцінювання знань, які були реалізовані в Австрії досить пізно, порівняно 3 аналогічними змінами в Німеччині та Швейцаріі. Такі заходи, як розподіл функцій учасників (кафедри не беруть участі у проведенні незалежного тестування, вони тільки готують банк тестових завдань), прозорість процедур, можливість доступу до бази завдань, що виносяться на іспит, і перегляду своїх результатів після іспитів, постійне застосування “принципу чотирьох очей” для контролю якості тестових завдань, обговорення проблем щодо проведення іспитів під час спілкування зі студентами, застосування об'єктивних методів оцінювання та наявність зворотного зв'язку за результатами проведення незалежного оцінювання значно покращили якість цього ключового чинника освіти, який був дуже неструктурованим і ненадійним у минулому [6].

У результаті акцентування уваги на навчання й оцінювання практичних вмінь і навичок були створені навчальні центри в усіх медичних навчальних закладах Австрії. Необхідність структурування та підтримки процесу викладання стали стимулом для використання стратегії електронного навчання [8]. 
Австрійські дослідники вказують на можливість виникнення проблем, коли будуть повністю реалізовані зміни в програмі. Однією з них є зниження продуктивності роботи, яке майже неминуче виникає, коли відмовляються від традиційних програм, за якими працювали багато років. Проблеми такого роду, ймовірно, мали місце в усіх університетах і розглядалися порізному. У Відні були зроблені деякі зміни і коректування початкових намірів, як описано в доповіді комісії з добровільної акредитації проекту. У медичному університеті Граца необхідно було подолати значний опір змінам, що і було зроблено шляхом ретельної зовнішньої експертизи. В Інсбруку нові методи оцінювання, які було заплановано спочатку, були призупинені, і комплексне оцінювання було відкладене до тих пір, поки всі студенти першого набору не завершили навчання за новим навчальним планом [8].

Значне скорочення відсіву і середньої тривалості навчання відкриває нові можливості для студентів. Хоча офіційні дані Міністерства відсутні, медичні університети звітують, що до завершення 12-14 семестрів навчання відсів складає менше $10 \%$. Це стосується не тільки кар'єри окремих студентів, алеіпланування розвитку людських ресурсів у секторі охорони здоров'я [11].

Змінюється також перехід від додимломної освіти до післядипломної. У двох університетах (Граца та Інсбрука) останній рік навчання передбачає виключно клінічну підготовку, у Віденському медичному університеті також відбуваються зміни в цьому напрямі. У поєднанні з існуючим каталогом кваліфікаційних вимог до дипломованого спеціаліста це сприятиме відповідності медичної освіти в усіх німецькомовних країнах, а значить індивідуальній мобільності і можливості для працевлаштування [9].

У зв' язку з новими вимогами щодо освітніх компетенцій (викладання, навчання, оцінювання, оцінка) 3'являються нові можливості для викладачів упрофесійній кар'єрі в галузі освіти. У 2009 році були реалізовані нові критерії заохочення викладачів усіх медичних університетів, що передбачає їх участь в освітніх проектах усіх європейських країн. Це, у свою чергу, вимагає структурованої програми для розвитку післядипломного навчання професорсько-викладацького складу університетів [8].

\section{Література}

1. Гіббс Т. Відкрите обговорення системи медичної освіти в Україні : на початку нової ери / Тревор Гіббс // Сімейна медицина. - 2008. - № 1. - С. 5 -6.

2. Медицинское образование в мире и в Украине / [Ю. В. Поляченко, В. Г. Передерий, А. П. Волосовец. и др.]. - Харь-
Міжнародні дискусії все частішестосуються Болонського процесу в медичній освіті. Суперечки про наявність одно- чи двоциклових навчальних планів часто затьмарюють інші важливі питання. Важливою особливістю австрійського підходу є вертикальна структуризація медичної освіти. Кваліфікаційний рівень “лікар” (шість років, 5500 годин) вважається професійною кваліфікацією. Найвищим рівнем відповідно до Болонського підходу є отримання ступеня доктора філософії (3 роки навчання після отримання диплома лікаря), що надає широкі можливості для професійної кар'єри в майбутньому. Таким чином, обидва рівні (доктор філософії і спеціаліст) чітко регламентовані. Впровадження базової кваліфікації бакалавра в галузі медицини стало можливим завдяки поправкам до Закону про університети 2009 року. Це відкрило можливість для впровадження курсу бакалавра, якщо в цьому буде термінова необхідність чи виникнуть додаткові можливості самореалізації (наприклад, міжпрофесійна освіта, робота усфері організації охорони здоров'я тощо) [5].

Важливим критерієм на міжнародному рівні $\epsilon$ мобільність, як протягом проходження курсу навчання, так іпіслядипломного навчання. Австрійський випускник унайближчому часі буде на рівних з випускниками інших німецькомовних країнах як формально, такіщодо якості їх освіти, і вони більше не будуть обтяжені недоліками (наприклад, щодо післядипломного навчання в Німеччині), які в даний час все ще існують [13].

Висновки. 3'ясовано, що проведення глобального реформування медичної освіти в Австрії було наслідком дії багатьох чинників. Зміни стосуються як дипломної, так і післядипломної освіти. Модернізація навчального плану істотно впливає на університетські інституції, які забезпечують координацію, фінансування, логістику, якість і підвищення кваліфікації викладачів. Зміни вплинули на студентів, які навчаються в принципово інших умовах (прийому, тривалості навчання, кваліфікації спеціалістів тощо).

Важливим активом австрійської системи є хороші можливості для співпраці між медичними університетами, які отримують вигоду від сумісних дій, створених спільними зусиллями, але всеж залишаючись автономним і здатними визначати свої власні стратегії розвитку і вдосконалення.

ков : ИПП “Контраст”, 2005.-464 с.

3. Evaluation des Studiums Humanmedizin an der Medizinischen Universitat Wien -,,Pilotprojekt Akkreditierung“ /Aretz T., Fischer M., Kadmon M. [et al.] Bericht des ReviewTeams. Wien: Osterreichische Qualitatssicherungsagentur; 